Piotr Russel

\title{
Ocena rządowego projektu ustawy o zmianie ustawy - Kodeks spółek handlowych oraz niektórych innych ustaw ${ }^{1}$
}

\begin{abstract}
Akcjonariusze prostej spółki akcyjnej (PSA) nie byliby zobligowani do pokrycia minimalnego kapitału zakładowego przed utworzeniem spółki ani nie ponosiliby odpowiedzialności za zobowiązania spółki. PSA będzie mogła być utworzona w każdym celu prawnie dopuszczalnym, nie tylko w przypadku nowych innowacyjnych projektów obarczonych dużym ryzykiem (tzw. startupów), ale również w sytuacji unikania odpowiedzialności osobistej za zobowiązania zaciągnięte przez spółkę. Zaproponowane w projekcie ustawy mechanizmy ochrony wierzycieli mogą okazać się niewystarczające do zaspokojenia wierzycieli PSA.
\end{abstract}

Słowa kluczowe: Kodeks spółek handlowych, projekt ustawy, przedsiębiorczość

Assessment of the governmental Bill on Amending the Act - Commercial Companies Code and Certain other Acts: Shareholders of a simple joint-stock company (PSA) would neither be obliged to cover the minimum share capital prior to the formation of the company, nor they would be liable for the company's obligations. The PSAs may be established for any legally permissible purpose, not only in the case of new innovative high-risk projects (start-ups), but also in situations where personal liability for liabilities incurred by the company is avoided. The creditor security mechanisms proposed in the bill may not be sufficient to satisfy PSA's creditors.

Keywords: Commercial Companies Code, bill, entrepreneurship

Doktor nauk ekonomicznych, Kolegium Zarządzania i Finansów w Szkole Głównej Handlowej, ekspert ds. systemu gospodarczego BAS • piotr.russel@sejm.gov.pl •

https://orcid.org/0000-0001-5749-8952

\section{Zakres przedmiotowy ustawy}

Zakres przedmiotowy projektowanej ustawy obejmuje wprowadzenie do polskiego porządku prawnego nowego rodzaju spółki kapitałowej w postaci prostej spółki akcyjnej (dalej: PSA), która miałaby funkcjonować zgodnie z następującymi założeniami:

- minimalny kapitał akcyjny w wysokości 1 zł oraz rezygnacja z nominałowego charakteru akcji, co oznacza oderwanie praw korporacyjnych od kapitału, - możliwość elastycznego kształtowania struktury majątkowej spółki na podstawie akcji bez wartości nominalnej,

$1 \quad$ Ocena skutków regulacji zawartych w rządowym projekcie ustawy o zmianie ustawy - Kodeks spółek handlowych oraz niektórych innych ustaw (druk sejmowy nr 3236) sporządzona 8 marca 2019 r. na zlecenie zastępcy Szefa Kancelarii Sejmu; BAS-WASiE 314/19. 
- znaczna swoboda wypłat z kapitału akcyjnego - brak związania środków odpowiadających kapitałowi akcyjnemu na wzór podobny do kapitału zakładowego występującego w spółce z o.o. oraz spółce akcyjnej,

- zakaz dokonywania wypłat na rzecz wspólników, które prowadziłyby do utraty płynności finansowej spółki oraz obowiązek dokonywania odpisu w wysokości co najmniej $8 \%$ z zysku za dany rok na kapitał akcyjny dopóki kapitał ten nie osiągnie 5\% sumy zobowiązań spółki wynikającej z zatwierdzonego sprawozdania finansowego za ostatni rok obrotowy,

- wprowadzenie rozwiązań umożliwiających wniesienie do spółki pracy i usług bez konieczności sporządzenia wycen na etapie rozpoczynania działalności,

- prosta rejestracja elektroniczna za pomocą formularza (wg ustawodawcy proces ten nie powinien trwać dłużej niż 24 godziny) oraz wykorzystywanie środków elektronicznych w funkcjonowaniu spółki,

- uproszczenie funkcjonowania spółki, m.in. przez wprowadzenie uproszczonej dematerializacji akcji w rejestrze i szerokie wykorzystanie środków komunikacji elektronicznej w procesach decyzyjnych,

- brak obowiązku ustanawiania rady nadzorczej,

- uproszczona procedura likwidacji spółki w razie niepowodzenia przedsięwzięcia lub przekształcenia w inną spółkę kapitałową.

\section{Podmioty, na które oddziałuje akt}

Zakres oddziaływania projektowanej regulacji jest szeroki i obejmuje m.in. następujące podmioty:

- osoby fizyczne zainteresowane założeniem działalności gospodarczej w nowej, uproszczonej formie - liczba trudna do oszacowania,

- istniejące na rynku spółki kapitałowe, tj. spółki z ograniczoną działalnością oraz spółki akcyjne (z wyłączeniem spółek notowanych na Giełdzie Papierów Wartościowych), które mogą być zainteresowane przekształceniem spółki w nowy typ spółki kapitałowej (łączna liczba takich podmiotów jest szacowana na ok. 464 tys.),

- podmioty, które mogą być zainteresowane inwestowaniem w nowe przedsięwzięcia inwestycyjne o relatywnie wysokim poziomie ryzyka - liczba trudna do oszacowania,

- podmioty uprawnione do prowadzenia rachunków papierów wartościowych zgodnie z przepisami o obrocie instrumentami finansowymi (m.in. domy maklerskie, banki prowadzące działalność maklerską, zagraniczne firmy inwestycyjne działające na terytorium RP) oraz notariusze - podmioty te uzyskałyby uprawnienia do prowadzenia rejestru akcjonariuszy PSA (łącznie ok. 5,5 tys.),

- sądy rejestrowe oraz wydziały gospodarcze Krajowego Rejestru Sądowego - podmioty te przeprowadzałyby rejestrację nowego typu spółki kapitałowej, 
postępowania dotyczące zezwolenia na rozwiązanie spółki bez likwidacji przez przejęcie majątku spółki przez oznaczonego akcjonariusza, a także rozpoznawałyby sprawy dotyczących przekształcenia PSA,

- sądy okręgowe - podmioty te byłyby odpowiedzialne za rozpoznawanie środków zaskarżenia od postanowień sądów rejestrowych dotyczących PSA, rozpoznawałyby sprawy o ustalenie wartości godziwej udziałów lub akcji oraz sprawy dotyczące przekształcenia PSA,

- Sąd Najwyższy, który odpowiadałby za rozpoznawanie skarg kasacyjnych na postanowienia sądu drugiej instancji w przedmiocie wykreślenia PSA z rejestru (zarówno w przypadku rozwiązania spółki, jak i przejęcia majątku spółki przez jednego akcjonariusza),

- Minister Sprawiedliwości - w zakresie modyfikacji systemów teleinformatycznych Krajowego Rejestru Sądowego oraz wydania rozporządzenia określającego wzorzec umowy PSA, a także wzorce uchwał i innych czynności wykonywanych w systemie teleinformatycznym.

\section{Celowość wprowadzenia aktu}

Celem projektowanej regulacji jest wprowadzenie do praktyki gospodarczej nowego typu spółki kapitałowej w formie tzw. prostej spółki akcyjnej, co ma ułatwić podejmowanie i prowadzenie działalności gospodarczej oraz zwiększyć możliwości inwestycyjne polskich przedsiębiorców.

Zgodnie z załączoną do projektu oceną skutków regulacji ewaluacja ex-post zostałaby przeprowadzona przez Ministerstwo Przedsiębiorczości i Technologii w roku 2023, po trzech latach od dnia wejścia w życie ustawy. Zgodnie z założeniami ewaluacja zostanie dokonana w na podstawie porównania - w każdym z trzech lat obowiązywania ustawy - „współczynnika wyznaczonego przede wszystkim przez iloraz liczby wszystkich utworzonych spółek kapitałowych i liczby utworzonych prostych spółek akcyjnych". Zaproponowany miernik budzi wątpliwości. Wydaje się, że zaproponowane miary powinny uwzględniać efektywność proponowanej formy prawnej, tj. badać, jaki odsetek nowo utworzonych (a nie przekształconych) podmiotów w formie PSA prowadzi działalność np. po dwóch latach od rozpoczęcia działalności gospodarczej, jaką dynamiką cechuje się poziom przychodów ze sprzedaży lub wielkość zatrudnienia wśród tego typu podmiotów.

\section{Planowane środki (narzędzia i działania) realizacji celów}

Powstanie nowego typu spółki kapitałowej, która zgodnie z założeniami ustawodawcy, ma być nowoczesną formą niepublicznej spółki kapitałowej przeznaczo- 
ną dla innowacyjnych przedsięwzięć, może w praktyce prowadzić do nadużyć i zmniejszać bezpieczeństwo obrotu gospodarczego. Projektowane rozwiązania zakładają bowiem, że nowa forma prawna będzie mogła być wykorzystywana w każdym celu prawnie dopuszczalnym, jak również dopuszcza możliwość przekształcania już istniejących spółek kapitałowych w PSA. Dodatkowym problemem może być sama nazwa „prosta spółka akcyjna”, gdyż łatwo wprowadza w błąd jej potencjalnych kontrahentów, którzy mogą kojarzyć ją z tradycyjną spółką akcyjną, wyposażoną co najmniej w minimalny kapitał zakładowy wynoszący 100 tys. zł.

Wydaje się, że alternatywnym rozwiązaniem dla tworzenia nowego typu spółki kapitałowej mogłoby być znowelizowanie przepisów regulujących zasady działania np. spółki z o.o. lub komandytowo-akcyjnej tak, aby jej przepisy mogły być jak najszerzej wykorzystywane przez nowo tworzone podmioty gospodarcze, a w szczególności innowacyjne startupy. Innym możliwym rozwiązaniem byłoby przyjęcie zasady, że forma prostej spółki akcyjnej mogłaby być wykorzystywana tylko przez określony czas, np. 2-3 lata od momentu rozpoczęcia działalności, tak aby istniała możliwość rynkowego zweryfikowania innowacyjnej koncepcji biznesowej. Po upływie tego okresu istniałby obowiązek przekształcenia prostej spółki akcyjnej w tradycyjną spółkę kapitałową (akcyjną lub z ograniczoną odpowiedzialnością).

\section{Ocena kosztów i korzyści}

Wśród potencjalnych korzyści wynikających z przyjęcia projektowanej ustawy można wskazać kompleksowe uregulowanie w polskich przepisach prawnych uproszczonej formy prowadzenia działalności gospodarczej, która mogłaby być atrakcyjna w szczególności dla nowych innowacyjnych projektów gospodarczych, obarczonych dużym ryzykiem niepowodzenia. Przy projektowaniu tego typu rozwiązań należy jednak zwrócić uwagę na potencjalne ryzyka, które wiążą się z projektowanymi przepisami:

- minimalna wysokość kapitału akcyjnego w projektowanej PSA ma wynosić 1 zł, co jest wartością znacznie niższą aniżeli minimalna wysokość kapitału zakładowego w spółce akcyjnej (100 tys. zł) oraz spółce z ograniczoną odpowiedzialnością ( 5 tys. zł) - tym samym kapitał podstawowy w PSA może być jeszcze niższy niż w spółce $z$ o.o. i tym samym nie będzie on stanowił żadnej ochrony wierzycieli spółki,

- PSA będzie mogła być tworzona w każdym celu prawnie dopuszczalnym, a więc nie tylko w przypadku nowych innowacyjnych projektów obarczonych dużym ryzykiem, ale również będzie możliwe przekształcanie już istniejących spółek kapitałowych w PSA, co stwarza ryzyko powstania pewnego rodzaju arbitrażu regulacyjnego, który w konsekwencji może prowadzić do zmniejszenia bezpieczeństwa obrotu gospodarczego, 
- zaproponowany w projektowanych regulacjach mechanizm zakładający konieczność dokonywania odpisu w wysokości co najmniej 8\% z zysku za dany rok na kapitał akcyjny dopóki kapitał ten nie osiągnie 5\% sumy zobowiązań spółki wynikającej z zatwierdzonego sprawozdania finansowego za ostatni rok obrotowy należy uznać za słuszny, ale niewystarczający do uregulowania zobowiązań wobec wierzycieli spółki; w szczególności przedsiębiorstwa typu startup w początkowym okresie funkcjonowania często generują straty, co uniemożliwia im rozpoczęcie „oszczędzania” środków mogących stanowić zabezpieczenie dla wierzycieli; ponadto $5 \%$ bufor jest relatywnie niski i nie pozwoli na zaspokojenie roszczeń wierzycieli,

- tylko w niewielkim stopniu ochronę wierzycieli poprawia projektowany przepis art. $300^{131}$, który przewiduje odpowiedzialność członków zarządu w sytuacji bezskutecznej egzekucji z majątku spółki. Członek zarządu może bowiem uwolnić się od tej odpowiedzialności, jeżeli wykaże, że we właściwym czasie zgłoszono wniosek o ogłoszenie upadłości lub w tym samym czasie wydano postanowienie o otwarciu postępowania restrukturyzacyjnego albo o zatwierdzeniu układu w postępowaniu w przedmiocie zatwierdzenia układu, albo że niezgłoszenie wniosku o ogłoszenie upadłości nastąpiło nie z jego winy, albo że pomimo niezgłoszenia wniosku o ogłoszenie upadłości oraz niewydania postanowienia o otwarciu postępowania restrukturyzacyjnego albo niezatwierdzenia układu w postępowaniu w sprawie zatwierdzenia układu wierzyciel nie poniósł szkody. Zaprezentowane wyżej przesłanki zwolnienia członka zarządu z odpowiedzialności wskazują, iż w praktyce tylko w nielicznych sytuacjach będzie można dochodzić swoich roszczeń bezpośrednio od podmiotów zarządzających prostą spółką akcyjną,

- fakultatywność powoływania w PSA rady nadzorczej, co może zmniejszać wewnętrzne mechanizmy kontrolne spółki.

Należy dodać, że negatywną opinię o projekcie ustawy wydała Rada Legislacyjna przy Prezesie Rady Ministrów, która w konkluzji stwierdza: projekt nowelizacji k.s.h. z dnia 15 maja 2018 r. wprowadzający prostą spółkę akcyjna rodzi tak duża ilość wątpliwości i zastrzeżen, iż w tym kształcie winien zostać skierowany do dalszych prac analitycznych przy udziale środowiska naukowego. Wprowadzenie tego projektu może bowiem godzić w bezpieczeństwo obrotu prawnego przez faktyczne wprowadzenie do prawa polskiego zamiast prostej spółki akcyjnej tzw. „spółki akcyjnej bis” czy „spółki akcyjnej light”. Projektowana regulacja nie uwzględnia przepisów dotyczacych pozostałych spółek kapitałowych, co przejawia się m.in. w tworzeniu własnej siatki pojęciowej. Wywoła to z kolei fundamentalne trudności interpretacyjne na gruncie regulacji istniejących spółek akcyjnych. Tym samym przedłożony do zaopiniowania projekt $w$ istocie swej nie spełni zasadniczego celu, jaki został sformułowany w uzasadnieniu, a polegajacy na ukształtowaniu „nowoczesnej spółki niepublicznej dla nowoczesnej gospodarki”, a w szczególności 
spółki przeznaczonej do realizacji nowych przedsięwzięć podejmowanych $w$ warunkach dużej niepewności rynkowej, czyli tzw. startupów.

\section{Podsumowanie - ogólna ocena projektu}

- Projektowana regulacja ma na celu wprowadzenie do polskiego porządku prawnego nowego rodzaju spółki kapitałowej w postaci tzw. prostej spółki akcyjnej, której akcjonariusze nie byliby zobligowani do pokrycia minimalnego kapitału zakładowego przed utworzeniem spółki ani nie ponosiliby odpowiedzialności za zobowiązania spółki.

- PSA będzie mogła być utworzona w każdym celu prawnie dopuszczalnym, a więc nie tylko w przypadku nowych innowacyjnych projektów obarczonych dużym ryzykiem (tzw. startupów), ale również w sytuacji unikania odpowiedzialności osobistej za zobowiązania zaciągnięte przez spółkę.

- Projektowane przepisy zakładają możliwość przekształcania już istniejących spółek kapitałowych w PSA, co stwarza ryzyko powstania pewnego rodzaju arbitrażu regulacyjnego, który w konsekwencji może prowadzić do zmniejszenia bezpieczeństwa obrotu gospodarczego.

- Zaproponowane w ustawie mechanizmy zabezpieczenia wierzycieli w postaci obowiązkowych odpisów z zysku, zakazu wypłat, które zagrażałyby wypłacalności spółki oraz odpowiedzialności zarządu w sytuacji braku możliwości egzekucji z majątku spółki mogą okazać się niewystarczające do zaspokojenia wierzycieli PSA.

- Negatywną opinię o projekcie ustawy wydała w czerwcu ubiegłego roku Rada Legislacyjna przy Prezesie Rady Ministrów. 